\section{DIETARY STUDIES OF UNDERNOURISHED SCHOOL CHILDREN IN NEW YORK CITY*}

\section{E. MATHER SIIL, M.D.}

Attending l'hysician at the Good Samarltan Dispensary, Chllden's vepartment; Lecturer in Diseases of Chlldren at the New York Polyclinle Medical School and llospital NEW YORK

The average person selects the different food materials in the market with verv little knowledge of their actual nourishment value. When the income of the family is so limited that every cent must be made to go as far as possible, which is true of the average family living in the "poor" quarters of our great cities, then it is evident that ignorance of food values must mean much unnecessary expense, and perhaps suffering to those who can ill aftord it.

My previous studies of 1,200 malnourished school children and the wide-spread interest shown as a result of my article on that sulject have prompted me to further and deeper studies along this line, the result of which I now hay before you.

In order to make these dictary studies I have followed the plan of Atwater, since that seems to be the most aceurate. Thus careful and accurate account was kept of the kinds, anounts, composition and cost of all food materials caten during ten days, which was the period of investigation, and to insure accuracy the period should? not be less. From this the cost, nutrients, and fuel value per man per day were computed in cents, grams and calories; the composition of ench material used as shown by analysis, and the amounts of the different nutritive ingredients were determined. An account wns kept of all the meals taken by each member of the fumily, as well as visitors or bonrders, should there be any during this period of investigation.

The factor's used in calculating the meals consumed in these dietary studies, were those commonly recognized as being the standard and were taken from Atwater's latest work, namely:

A nan at lard muscular work requires 1.2 the food of a mun at moderately active work.

A man with light muscular work and a boy 15 to 16 years old require 0.0 the food of a man at moderately active work.

A man at sedentary occupation, a woman at moderately active work, a boy 13 to 14 , and a girl 15 to 16 years old require 0.8 the food of a man at moderately active museular work.

A womm at light work, a boy 12 or girl 13 to 14 years old require 0.7 the food of a man at moderately netive muscular work.

A boy 10 to 11 and a girl 10 to 12 years old require 0.6 the food of a man nt moderately active muscular work.

A child of to 9 years old requires 0.5 the food of a man at moderately active muscular work. A child 2 to 5 years old requires 0.4 the food of a man at moderntely active muscular work. $\Lambda$ child inder two years old requires 0.3 the food of a man at moderately active muscular work.

It is by the use of these factors that the number of meals actually taken by each member of the family is computed in terms equivalent to the number of meals for an adult man. Thus the total number of meals taken by the family is expressed.in terms of meals per man, which, being divided by the number of meals per day, which is three, the number of days for one man is obtained. The total nutrients of the food eaten

- Real in the Section on Diserses of Children of the American Medical Assoctation, at the Sixty-first Annual Session, held at $\mathbf{S t}$ Louls, June, 1010 . divided by the equivalent number of days for one man gives the amount per man per day.

\section{DIETARY STANDARDS}

$\Lambda$ twater reports studies of twelve laborers' families with ordinary work in large cities in the United States, in which the averages were per man per day, protein 101 gm., fat $116 \mathrm{gm}$., carlohydrates $344 \mathrm{gm}$., with a fuel value of 2,810 calories, which is an insufficient diet, according to the standards.

In eleven poor families in New York City the averages of the food actually eaten were protein $93 \mathrm{gm}$., fat 95 gim., carbohydrates $407 \mathrm{gm}$., and fucl value 2,845 calories.

In ten Russian Jewish families in Chicago the averages were, protein $137 \mathrm{gm}$., fat $103 \mathrm{gm}$., carbohydrates $418 \mathrm{gm}$., and fucl value 3,135 calories actually taken per. man per day. These are enough quotations of previous studies to make our comparison.

'The dietary standards as given by Atwater, and which have been pretty generally accepted, are as follows:

A man with harl muscular work, protein $175 \mathrm{gm}$. (or 0.39 pounds) with fat and carbolyydrates in sufficient amounts to produce a fuel value of 5,500 calories.

A man with moleratcly active muscular work, protein 125 gm. with fat and carbolydrates enough to produce a fuel value of 4,150 calories.

A man with light to moderate museular work, protein 112 gm. (or 0.28 pounds) with fat and carbohydrates enough to produce a fuel value of 3,400 calories.

A man nt "sedentary" or a woman with moderately netive work, protein $100 \mathrm{gm}$. (or 0.22 pounds) with fat and carbohydrates enough to produce $a$ fuel value of 2,700 calories.

A woman at light or moderately muscular work, or a man without muscular exercise, protein $90 \mathrm{gm}$. (or 0.20 pounds) with fat and carbohydrates enougin to produce a fuel value of 2,450 calories.

The average of twenty-eight dietaries studied by me showed the following per man per day (all the families having malnourished children) :

Cost 19 cents, protein 95 gm., fat 68 gm., carbolyydrates $407 \mathrm{gm}$., calories 2,614. These all did active or moderately active work.

Some six of these dietaries were up to or above the recognized standards, and therefore raised the general average considerably, but most of the dietaries were considerably below the ordinary standard, few being up to 3,000 per man per day, and some as low as 1,600 calories per man per day, with corresponding low fat, proteid, and carbohydrates, thus showing the undernourished condition due to lack of proper food.

In those families whose dietaries were up to or above the standard there were always other good and sufficient reasons for the malnutrition of the clildren, such as close quarters, overcrowding, late hours, infrequent bathing, eating candy between meals, and tuberculous infection, or convalescence from disease; also adenoids and enlarged tonsils in some cases, or organic disease.

Dietary studies of six fairly well-to-do families, at moderately active nuscular work, showed averages per mun per day as follows:

Cost 35 cents, protein 149 gm., fat $115 \mathrm{gm}$. , carbohydrates $569 \mathrm{gm}$., and calories 3,884. Thus it will be seen these six families had about sufficient food and a fairly nourishing diet, and the adult members were well nourished. I could attribute the malnourished condition of the children only to the fact that they ate cheap candy between meals and thereby spoiled their appetites for nourishing food, lived in crowded quarters, sat up lat? at night, had organic disease, or were convalescing from 
disease. All of these were good reasons for their condition.

Another fact that has been most strongly impressed on my mind in making a record of each child's meals is that most of them ate very little in the way of breaklast and that the nutriment which they obtained from that meal was entirely inadequate for the demands of the growing boly. The average breakfast of these children consists of tea or coffee and bread, and the consequence is that many are so hungry in school that they cannot concentrate their minds on study.

From a previous study of the meals of 210 malnourished children, I found that the following breakfasts were given.

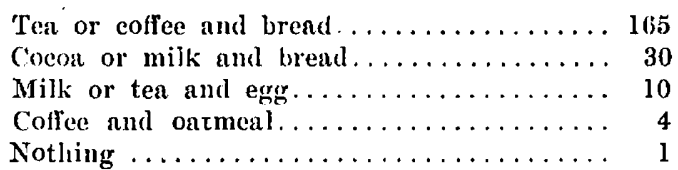

It is well known that breakfast is the important meal for the growing child.

Dr. H. M. Lechstrecker, of the New York State Board of Charities, examined 10, 707 children in industrial schools of New York, with the following result: 998 had coffee or coffee and bread only for breaklast; 439 had no breakfust; 998 were anemic owing to lack of nourishment. Only 1,855 , or 17.32 per cent., started the day with an adequate meal.

These studies were carried on among families of the poorer classes, living on the lower "East Sirle" of New York City, below Fourteenth Street, and east of Third Avenue and the Bowery. The families studied were representative of the people in this district and a large number of occupations were represented. Dietary sturdies were made from thirty-four families. Some were found to be shiftless and slovenly and took no interest in liaving a clean, comfortable home and setting an attractive table, while others, though ignorant, were willing and desirous of learning how they could improve their way of living and dietaries.

The range in total income per family was from an amount not sufficient to buy the absolute necessities of life, to an amount which should be ample for their needs and equal to that on which other families have been found to live comfortably. In no case among poorer families was there any food used which required cure or work in preparing; whether this was from ignorance, lack of energy, opportunity, or convenience, it is hard to say; each cause no doubt was a factor to a certain extent, but ignorance seemed to be the principal reason.

The studies were carried on and the final results calculated according to the methods of Professor Atwater. Practically all this computing work has been done with a calculating machine, but even with this great aid the amount of detail work was considerable. 'I'he data obtained in each family studied was (1) the nationality. age, sex, occupation of each member of the family; (2) the income of the family; (3) the expenditures for rent, and food, gas, coal, etc.; (4) the kind, quantity and quality of food consumed; $(5)$ the number of meals taken by each person present during the study.y From these data, and the standard tables showing the composition and fuel value of the different food materials used, the quantities of nutrients and energy consumed per man per day were computed.

This made it possible to compare results with recognized standards and to judge whether the families were receiving proper nourishment, and whether they used good judgment and intelligence in the selection and purchase of food, and also to point out how a more mutritious diet in many cases could be purchased for the same amount of money or as nourishing a diet for less money.

In thirty-four such dietary studies made, twentyeight dietaries were found to be deficient in protein, fat, and carbohydrates, with a corresponding low fucl value per man per day, and by multiplying these results by the factor used according to the ages of the undernourished child we obtain a diet correspondingly low for it.

'The average of thirty-eight dietary studies of fairly well nourished families made in the United States of persons at moderate work, showed that these persons received $134 \mathrm{gm}$. of fat, $487 \mathrm{gm}$. of carbohydrates, in combination with $102 \mathrm{gm}$. of protein.

But the average of twenty-eight dietary studies that I have made gave protein $95 \mathrm{gm}$, fat $68 \mathrm{gm}$. , carbohydrates $40 \%$ gm., thus showing great deficiency in all the food ingredients.

The average of these thirty-four dietary studies showed that 61 per cent. of the money spent was for animal foods, and 39 per cent. for vegetable fools, and about the same amount of protein was obtained from the animal as from the vegetable foods (slightly more from the vegratable foods. About five times as much fat was obtained from the animal as from the vegetable foods, or over 80 per cent. Over 70 per cent. of the carbohydrates came from the vegetable foorls and more than twice the number of calories were obtained from the vegetable food as from the animal food. 'The carbohydrates furnished by the animal food came mostly from the milk.

In the studies of nearly 200 dietaries in families of widely varying circumstances in different parts of the country, it was found that the various animal foods made up about one-fifth of the total amount of food. and furnished more than six-tenths of the protein and nine-tenths of the fat used. My studies would indicate then that these thirty-four families with undernourished children got less than five-tenths of their protein from animal food and eight-tenths of their fat from the same source.

The fuel value of each food used in these dietaries was computed by means of values previously obtained from the stadies of Professor Atwater, and others, by the use of the bomb and respiration calorimeters, which give for our common foodstuffis as ordinarily used in diets, the following general estimates for the energy furnished to the body by $1 \mathrm{gm}$. or 1 pound of each of the different classes of nutrients (calling an avoirdupois pound equal to $450 \mathrm{gm}$.) ; to be mathematically exact it should be $453.7 \mathrm{gm}$. to the pound. Protein, fucl value, 4 calories per gram, or 1,820 calories per pound. Fats, fuel value 9 calories per gram or 4,040 calories per pound. Carbohydrates fuel value, 4 calories per gram, or 1,820 calories per pound.

'Thus it will be seen, having this data and the percentage of fat, protein and carbohydrates in each article of food as per analysis, ${ }^{1}$ in order to ascertain the number of grams of protein, fat, and carbohydrates in each variety of food, one should find first the total number of grams weight by multiplying the weight of food by 450 , the number of grams per pound avoirdupois, and multiply this result by the per cent. of protein, fat, and carbohydrates as shown by chemical analysis to be present in each article. 1. Atwater, W. O.: Princlpleg of Nutrition and Nutritivis
Valie of Food. Filmer's Bull. 142, U. S. Uept. Agric., corrected 10 Apill 5, 1000 . 
IMIPROVEMENT OF DIETARIES BY TNOWLEDGE OF FOOD VALUES AND PROPER SELECTION OF FOOD

Almost all dietaries studied could have been improved both from a nutrient and an expense standpoint. In practically all a very small amount of the cereals, such as oatmeal, hominy, corn meal, rice, cracked wheat, ete., were purchased; also a very small fraction of the dict was made up of the dried legumes (beans, peas, lentils) although more nutriment (protein) can be obtained from these (properly cooked) for a given sum of money than from any other foods. It is well known that protein is the most important ingredient of food as it is the tissue builder, since it is the basis of muscle, bone and almost all the tissues and fluids of the body, hence its importance to the growing child. The cost of dried beans was $(i$ cents a pound and the cost of cerenls by bulk the same.

The bulk of the nourishment in these diets was obtained from meat, milk, and bread and rolls. Baker's bread was used almost entirely, and the rolls used were purchased from the baker. 'This bread was rye and varied in price in the different families from 1.3 cents to 4 cents per pound and the rolls were made of white flour and were more expensive, costing about three times as much per pound as the bread. The majority of families paid from 3 to $3 \frac{1}{2}$ cents per pound for their bread. Those that paid less got stale bread, which is just as nutritious and healthful, and much more cconomical.

There is no doubt that it would have been better economy had they bought the flowr and made their own bread at home if it could have been baked while the fire was being used for cooking other things, so that there would be no waste of fuel.

The milk used cost from 5 to 9 cents a quart, the cheaper grade being obtained from the groceries from the can in bulk, while the more expensive grade was delivered at the house in sealed quart bottles. For many of the poorer families more nourishment could have been obtained for the same amount of money by the purchase of skimmed milk.

The meat used by practically all the families was chuck and flank of beef, which cost them 16 to 18 cents a pound, and this was about as economical fresh meat as they could have purehased for its nutrient value; corned beef, however, might have been used part of the time to advantage with less cost.

Some of those in better circumstances bought round steak, and chicken, the chicken being an extremely exponsive article of diet, for its food value, as it was purchased in small quantities, a small portion of a chicken such as a quarter at a time, which cost them anywhere from 15 to 28 cents a pound. Nearly all used fish in moderate guantities, principally carp, pike, buflalo fish, and salt herring.

One family received the same number of grams of protein, but six times as many grams of fat, and nearly as many calories from 2 pounds of herring at 15 cents as from 4 pounds of carp at 40 cents. Comparatively few agos were used during the time of year these dietary studies were made, which was February, Marel and April, and those used cost from 36 to 40 cents a dozen, which made them an expensive food.

$\Lambda$ few families bought a quart of strawberies every day at 10 cents, while others spent considerable tor mineral water, and alcoholic drinks, all of which had very little food value, and were wore or less injurious to health.

\section{THE NEED OF MORE THOROUGH : INSTRUCTION IN TII SCHOOLS}

It is most important that the coming generation of young girls should be thoroughly educated as to the comparative nutritive value of the different foods; how these foods may be best cooked to make them nourishing and appetizing and the proper dietaries for different ages and occupations. This branch of their education has been heretofore much neglected and holds only an interior place in their school curriculum. As the ultimate vocation of practically all is motherhood, it is far more important that they be educated in branches which will always be of value to them than that their minds be filled with languages and higher mathematics. The same girls who are now being educated will be future wives, mothers and housekeepers, and the knowledge gained in these matters will not only be of inestimable value to them in their families, in the economical purchase and cooking of food, and proper feeding of their children so that they will develop into strong and healthy men and women, but by their examples and modes of living they will educate their offspring along these lines of better living and gradually improve the nation.

It is well known that insufficient and poorly cooked food, coupled with meals uninvitingly and unattractivelv served, are the forerunners of alcoholism, drunkenness, crime and disease. Of 101 malnourished school children tested 55 per cent. gave a positive reaction to the von Pirquet tuberculin test.

By keeping our citizens and their children well nourished much will be. done toward preventing the spread and ravages of the great white plague. The best way of accomplishing this, then, is by educating the children along these lines in the public schools. A more systematic study should be made of all the foods used as to their composition, best methods of cooking, amounts necessary and kinds best suited to different ages and occupations, and especially as to the importance of a wellcooked, wholesome and nourishing diet for the growing child. This should be gone into very thoroughly in the schools and more hours given to this most important branch.

Improvement must begin physically before any marked improvement can be made mentally, morally or spiritually, and physical development depends on the right nutrition of the body. There should be cooking classes conducted by competent cooks and teachers thoroughly trained and educated in cooking, food values, dictetics, economics, ete.

Dietaries for families with different incomes should be made out and the children taught to cook the articles suggested so that those with a limited income, as well as those better off, may be able intelligently to provide nourishing and appetizing food. It should not be lost sight of that sone variety in the dict is important as thereby the stimulation of the appetite and the esthetic taste is increased, although great varicty and choice of things out of season are not essential, which should be borne in mind when strict economy must be practiced.

No girl should be entitled to a graduation certificate or working papers until she has passed a rigid examination covering these subjects; and boys should be taught also the different ingredients of foods, and which foods are most healthitul, nourishing and economical to buy, as well as the amount of protein, fat, and carbohydrates and number of calories necessary for proper nourishment at the different ages and in different occupations, 
the balanced diet and how best to obtain it. Children and adults alike should be taught that "the most healtlful food is that which is best fitted to the uses.".

"The cheapest food is that which furnishes the largest amount of nutriment at the least cost, and the best food is that which is both healthful and cheapest" (Atwater).

\section{INSTRUCTION FOR MIOTIIERS}

Passing from the education of the children we come to the jmmediate needs of providing a suitable, nourishing, and appetizing diet for the families. To accomplish this we must educate the mothers (for they purchase and cook the food for the family) along the same lines as those advocated in the schools. Something can be done by means of free lectures, free cooking classes, the distribution of pamphlets and other literature printed in diflerent languages, setting forth in simple language the best, most nomrishing, and most economical foods to purchase, and how to cook and serve these simple wholesome foods to make them inviting and appetizing, so that a small expenditure may return an anple nutriment ralue.

It is my belief, however, that only a small number of the poor and igmorant can be educated by these means; they must be reached in other ways; as. for instance, through large organizations such as the Woman's Christian Temperance Union, the Salvation Army, the American Federation of Labor, the Young Men's Christian Association, and others equally far-reaching. The United States government, and the press, through the large daily papers and other widely read publications can most effectually reach the masses, since conditions found in New York City obtain in other large cities of America as well. A scries of short articles should be written, setting forth in simple language proper diets, foods, proper methods of cooking, proper nutuition and the laws of growth, so that every wife, mother, and housckeeper might know and understand. There should be shown the high nutritive value of the cheaper fools as compared with those more costly, and methods of improved cooking. A great deal of food is badly cooked. If the cheaper foods well cooked replace the dearer kinds badly cooked, and the table be made attractive, there will result both saving in expense and happier and more contented home life. $\Lambda$ great deal can be done in this respect by individual and group talks to mothers and children in the dispensaries, giving rensons for the foods and cliets advocated. T'lis method I have pursued for many ycars with most gratifying results.

\section{REQUIREMENTS OF THE GROWING CHILD}

For the proper development and growth of a child, Nature demands that certain fixed and unchangeable rules be followed and when these rules are disobeved development and growth are impaired and often, as a result, disense follows.

$\Lambda$ child is a young animal and should be considered as such, and should at least have as much care and attention shown it as is given to our young animals. Thousands, lrowever, do not receive that care and attention on account of ignorance and neglect on the part of their parent.

Every clibld, to grow steadily in both mind and body and to be healthy must have nourishing, well-cooked food, suitable for its age and in sufficient quantities, given at regular intervals. Children are so active, and use up so much food in the shape of energy in that way, besides the food they need to develop the body and reuew the wear and tear of the body, that they require a highly nutritious djet, containing a high percentage of protein, and this is especially important where the child is malnourished.

A child requires long and regular hours of sleep, and under the age of 12 years every child should be in bed at 7 or 8 p. m. Children under 7 or 8 years, especially if undernourished, should have a nap of an hour or two during the middle of the day. In my studies of over 210 malnourished school children under 10 years of ase nearly 80 per cent. went to bed at 9 o'elock or later and the other 20 per cent. went to bed at 8 o'clock. The growing child to be well must be properly clothed, and have plenty of fresh air. Four or five hours out of doors every day are essential, and the sleeping rooms must be well ventilated at night.

livery normal child should have certain hours for play and certain hours for study. Tong hours in ill-ventilated school rooms for young children do great harm by undermining the health of the child, which is far more important than the learning he gets. Cleanliness is an inportant factor in the well being and health of every child, and a tub bath should be given at least once a week in winter and oftener in summer.

If children are given a fair chance by adhering to these principles and giving them only what every child in the land has a riglit to demand, they will he hardy and strong and grow like little animals.

iMPROPER AND UNSCIENTIFIC FEEDING DIRECTIX AND INDIRECILY TIIE CAUSE OF MANY AILMENTS

That improper and unscientific fecding of children from the time of birth to maturity is one of the most fruitful causes, both directly and indirectly, of disease, disability, incapacity for work, both mental and physical, loss of energy, susceptibility to contract and inability to withstand disease, everyone who has had wide experience must admit. This paper, however, deals with the child after the stage of babyhood has passed; in other words, the school child, up to the age of 10 or 12 years.

My experience has been in treating hundreds of these children that they contract disease much more easily and have less power of resistance than well-nourished children, and when disease is contracted it is apt to be more severe and prolonged. These children have so little reserve force to fall back on that when they have to undergo a severe illness, or operation, they are apt to succumb.

Ill-nourished children are especially subject to catarthal affections of the nose and throat and to bronchitis: they also are very susceptible to cold, and easily affected by it. Many are aflected with or subject to rheumatism, articular and muscular, and rheumatic sore throat; also not a few have chorea and rheumatic endocarditis.

All of these clildren are easily fatigued, both mentally and physically and have not the capacity for work that we see in well nourished children. Many of them have a tired, worn, inattentive look, complain of feeling tired and cannot concentrate their attention for any length of time, and their gaze is constantly wandering. They are anemic; their brains, as well as their bodies, are starved for want of nourishment. Many of them are put down in the schools as diullards, or backward children. In these cases good nourishing food is far more necessary for the stomach than books to feed the mind. It is an impossibility to concentrate the mind or to study on an empty stomach or when hungry.

In Fngland, Scotland and France, nourishing meals are given in many of the schools at slight cost. Tickets are issued which provide the children with healthful, 
sufficient breakfasts. These tickets are previously purchased by the parents. Many meals are given free, and no distinction is made between those who pay for their meals and those who are unable to do so. The person who distributes these meals cannot possibly know whether the tickets were paid for or whether they were a free gift to the child. It has been amply proved that this does not make either parents or children paupers, so the fear of making paupers is no argument against adopting such helpful measures in our own country.

THE GREATEST FIELD FOR THE IMIROVEMENT OF THE POOR IN GRLAT CITIES IS INSTIRUCTION ALONG - YIIESE LINES

The problem of nourishment which is so vital to the poor and the children of the poor, and the condition of our future population and nation at large so dependent on the way her children are nourished, that it should receive the attention of all.

We find by our studies that many poor families spend more than they can afford for food and yet receive insufficient nourishment by reason of their ignorance of food values. Attempt will be made in a general way to show how the expense for food can be reduced and yet a nourishing and wholesome diet procured. Fewer eggs and less butter can be used and the cheaper cuts of meat purchased and the difference thus saved can be expended for corn-meal, wheat-fiomr, cereals in bulk, jice, ontmeal, dried beans, potatoes, dried peas, lentils, whole milk and skimmed milk.

Where the income of the family is very small, meat can be replaced to a large extent by the above-named vegetables and cereals, which are much cheaper for their nutritive value. A large variety of fresh vegetables is not necessary or essential; they contain very little protein or energy, and where cost is considered one or two cheaper vegetables are sufficient. The cheaper cuts of beef contain more protein and fat and less waste than the more expensive cuts, and these with wheat-flour, bread, oatmeal, peas, and beans furnish abundant protein very cheaply.

The eheaper cuts of pork, flour, bread, sugar, cornmeal, potatoes, and rice furnish abundant fuel and ener'gy in a cheap form.

It has been found that the cheapest source of protein is the cereals; next comes meat; the most expensive be.ing fresh vegetables. Fancy high-priced firuits and those out of season should not be need.

The diet, as is well known, should vary somewhat with the climate and season of the year, and proper cook. ing of food is most important, making it more appetizing, more digestible, and more nomrishing.

In the majority of families among the poorer classes the food is pooily chosen, poorly cooked and poorly served, and in not a fow fanilies there is considerable waste, especially among those who are fairly well to do.

A carefully selected diet is necessary to keep the balance so that there may be as nearly as possible the right amount of fat, protein, or carbohydrates. Extremes of dict should be avoided, and a mixed balanced diet of protein. carbohydrates, and fat maintained.

Emphasis slould be laid on the necessity of setting a clean attractive table, having the meals eaten at regular hours, the whole family sitting down at the table together when the meal is warm.

If such standards can be thoroughly instilled into the minds of our poor people, more will have been accom- plished toward the improvement of the present condition of the poor, and the betterment and proper and normal development of their children, and the laying of the foundation for future better living, growth, and well being, than by any other means. Indeed, along these lines is the greatest field-for improvement of the poor in our great cities, and philanthropic movements should be directed towards this end.

Only those who see and treat thousands of these little undernourished, half-starved sufferers, as I do each year, can realize the appalling numbers, with their pitiful, cmaciated, hungry faces, and no one but he who has become callous from many such sights. constantly working among them, can look on this tragical scene $n$. moved.

142 West Seventy-Eighth Street.

\section{ABSTRACT OF DISCUSSION}

Dr. Wrlliam H. Welch, Baltimore: Dr. Sill has undoubtedly touched on the funclumental points. Those interested in the playground question in this country could render great aic in spreading information in regard to the matter of the food the child receives in its home. Dr. Sill spoke of the movement to furnish one meal, at lenst, in the schools; but objections have been urged to that on sociologic grounds. There is just one other point $I$ want to mention, and that is the question of skim-milk. There is no question of the value of skim-milk, but the regulation of the sale of skim-milk is somewhat of a problem to the health oflicer. We cannot permit the sale of skim-milk when it is likely to be mistaken by the purchaser for full milk. That was brought up by the Maryland State Board of Health. They showed me packages of full milk and packages of skim milk of the same size and the same colored label, which could not possibly be distinguished, except that one was marked, "skim milk." That won't do at all. The sale of skim milk cannot be permitted under such conditions. The packages should be different or so labeled that there cannot be any possibility of mistake between the skim milk and the full milk.

Dr. N. R. Concman, Columbus, Ohio: I must refer to the matter of giving children coffee. I cannot imngine anything more injurious for a child than to give it an article that will stimulate the vasomotor nerves, contract the blood-vessels and cut of nutrition, particularly the nutrition of the brain, that develops more rapidly than any other part of the body. I do not think any more deleterious habit could be practiced. It should be prohibited by law. Coffee, tea and cocoa, in my opinion, all have the same physiologic effect, but vary in degree. They should be spoken of in such a way, not only in this organization, but by the family physician, as to prevent, so far as possible, their use. Thirty years ago I called attention to this matter, and I have been preaching it ever since.

Dr. C. F. Wanner, Fort Madison, Ia.: There are three great faults of diet: eating too much, not eating enough and enting the wrong kind of food. Over the first two we have not much control, but the physician does have some control over the third. An excellent wave of reform is going over the land in regard to the tenching of girls in the classes of domestic economy, the proper foods and the proper way to prepare them. The physician does not realize the importance of giving out an outline of what to eat. I have a patient whom I have been treating six years for nephritis, and though she is four years overdue in heaven, she is still alive. 1 have another one, a man who came to me for nose-bleed due to acute nopluritis, and by regulating his diet he has not had another attack of nose-bleed. Another patient whom I had was a man who was asthmatic and could not go into a hay-field. It was all due to the horrible coffee he had been drinking. This man had been drinking collee made by his wife, who never emptied the pot from one day to another, simply adding a little more coffee ench time and letting it stand on the back of the stove to boil indefinitely. Her other 
cooking was equally skilful. I taught this woman how to make coffee, and her husband can now go into the hay-field without any difficulty. When a patient is told by a physician that he nust diet, lie goes on the theory that he must starve himself. The doetor does not tell him what to eat and what not to ent. And here we err. There are plenty of good books on the murket on dietetics. Buy them, inform yourselves, then give your patients definite rules as to what to eat and whint to avoid.

Dn. C. G. Knntwy, New York: Those of us who have seen much of life among the poor people in any large city will understand the truth of Dr. Sill's statement regarding their ignorance. I lave been in dispensary and hospital work for twenty-two years, and $I$ am impressed with the fact that it is not that these people lave not enough money, but that they have no illea of what constitutes nutritious food; and children ure not fed with the islea of body-building, but merely of satisfying the appetite. The mothers are not lay, they are untaught, and that is why they adopt a makeshift diet and do the thing that is easiest. If the physician takes the trouble to tell the nother what to do she does it. It is the primary function of the physician to instruct people how to live. That may be done through organizations of difrerent kinds. At jiresent there is an organization in New York (ity which will give a "child-welfare exhibit" in November. This exhibit will show educated people the conditions that exist among the joor, and it will be made attractive by olject lessons and demonstrations in order to draw the poor and show them the jesults which may be achieved by right living. By that exhibit a great deal will be accomplished. It will inform the best class of people low the others live and let the ignorant be talnglit what constitutes proper living.

Dr. S. W. Klituer, Cleveland: Just a word or two on the subject of meals, etc., for the child in school. The plan las, of course, its different sides, the question of pauperizing, and all that. We began with free schools and then free books, in some places free shoes, then free meals, free doctors, fren nurses, free dentists, and nearly every possible necessity for the ehild in school, until the tendency is to take the child out of the parents' hands too much and lenve the parents llothing to do but to bring the child into the world and turn it over to the State for its maintenance as well as for its education.

I hope that this work as it is now carried on is only a transitional stage, made necessary by the influx of ignorant and careless parents. I do not believe in letting the child sufier in the meantime. It must not be allowed to starve or to go unclothed while getting its education, but the parents must be educated in their duty as parents, and the coming gencration of paronts must be better informed and more attentive in their duties as parents. I believe that ultimately the duty of sehool boards will be confined to education. I think that they are outside of their proper function in furnish. ing physicians, nurses, dentists and food to school children. That, if temporarily necessary, can be carried on by other organizations. Of course, I believe in medical inspection, but school bonrds should confine themselves to education, even if that includes the education of the parents in many ways. The school authorities can call to their aid and cooperation other authorities and organizations, such as the juvenile courts, the lumane societies and the visiting nurses associntions. For instance, in the matter of meals the social settlement worker's can sce that the child gets well-prepared meals at home. In illness or malnutrition the physicians can instruct nurses and the nurses working among the people can carry out these instructions.

Dr. Chamles A. Catrilrmole, Boulder, Colo.: I want to explain a plan that is followed in the West. Dietetic errors are not so common in the West as among the people of the cities. The method we have adopted is to teach the girls in the high school the method of preparing food. They are taught cooking and buying of food in the market, and they cook und serve it in a proper way and get up a meal for the selrool board or a committee. In the cities children live on candies and prepared foods or go without breakfast.

\section{MINERS' CONSUMPTION}

OTTO V. HUFFMAN, M.D.

Medical Dlrector of Children's Department, Minml Valley Hospltal, and Physician-in-Chlef to Fruft and Flower Mission, Children's Clinic, at Ijayton, Ohlo

\section{CINCINNATI}

Miners' consumption is a term used by miners to designate emaciation associated with anemia, general weakness, shortness of breath and occasionally palpitation. It is distinctly a layman's term for a general condition which may be due to a variety of causes. Whocver has observed a large number of miners must have been struck with the fact that the majority are pale and thin, and that they present the facies of chronic dyspepsia. A low state of health among miners is so prevalent and the use of the term "miner's' consumption" so general that the subject merits the serious attention of the medical profession.

One does not have to look far for causes of ill health among the miner's. Most mines and mining towns are without any sanitary measures whatsoever. In the mine urine and feces are disposed of promiscuously. The Jniner's home is situated anywhere. 'The outhouse is nearly always on the hillside above the home, and of course the well below. The women and children seem to thrive regardless of filthy practices, however, so we musi look into the mine where the miner works for the clirect cause of his condition.

According to the returns of the 'Twelfth Census there were 528,822 persons in continental United States reported as "miners" in the year 1900. Of this number" 344,205 were reported as coal-miners; 52,024 as goldminers and silver-miners, and 132,593 as miners not specified.

Analyses reported by the Teclmological Division of the U. S. Geological Survey show that the atmosphere at the face of the coal in the mine contains nearly always traces of ethane, methane and carbon monoxid gases. In the ordinary management of a mine means are taken to detect these gases before they are present. in such a dangerous degree as to become inflammable. Ifficient forced ventilation will usually remove the gases in sufficient quantity to minimize the danger of an explosion, but at the face of the coal where the miner is working, there will always be traces of the above-mentioned gases. The stronger the ventilation, the greater the tendency to cxloaust in the rooms and blind entries, with greater liberation of gases from the newly made cuts, borcholes, and broken coal. In just what way the deleterious effects of ethane and methane are brought about when inhaled in small quantities over a long period we are not prepared to say, but we do know that carbon monoxid has the property of uniting with the hemoglobin of the red blood-corpuscles to form a rather stable compound, and that it is not readily replaced by ox.ygen.

In mines where dynamite and other nitroglycerin explosives are used we have another source of poison. In such explosives the nitroglycerin is mixed with inert matter. As a result of an explosion the inert matter is blown into the ore or conl. Adhering to the particles of this inert matter are small amounts of nitroglycerin which have been disseminated without entering into the detonation-being firmly fixed to the particles of the menstruum like so many tablets of nitroglycerin. Later this dust containing small amounts of nitroglycerin is inhaled 